\title{
2014 FIFA World Cup in Brazil: Gentrification of Brazilian Football
}

\author{
César Teixeira Castilho ${ }^{1,2, *}$, Babara Evrard ${ }^{3,4}$, Dominique Charrier ${ }^{1,2}$ \\ ${ }^{1}$ Cornell Institute of Archaeology and Material Studies (CIAMS), Cornell University, France \\ ${ }^{2}$ University of Orléans, France \\ ${ }^{3}$ Faculty of Science and Technology of Physical Activities and Sports (STAPS), University of Caen Normandy STAPS, France \\ ${ }^{4}$ Rouen University, France
}

Copyright $\mathrm{O} 2017$ by authors, all rights reserved. Authors agree that this article remains permanently open access under the terms of the Creative Commons Attribution License 4.0 International License

\begin{abstract}
This research focuses on the impacts of the 2014 FIFA Football World Cup on the Brazilian national football scene, especially in terms of its sporting infrastructure, relevant football bodies and fans of the national clubs. Through a qualitative approach based on a three-year longitudinal study (interviews, observations and documentary analysis) the theme was analyzed taking into account the importance of Brazilian football culture, whether as a sport or as a leisure activity, and the local aspects in four host cities of the competition: Belo Horizonte, Manaus, Recife and Rio de Janeiro. The results showed a profound modification of the country's stadiums infrastructure over the medium term, and a consequent gentrification of the fan base. Although managers of the country's top clubs are aware of these changes, the scenario for Brazilian football remains precarious when we consider the power of this sport within the country.
\end{abstract}

Keywords 2014 FIFA Football World Cup, Brazilian Football Culture, Gentrification

\section{Introduction}

Sporting mega-events are seen as an important aspect of the economic, social, tourism, and environmental transformation of the countries or cities that host them (Horne, 2007; Lim, 2013; Müller, 2015; Preuss, 2007; Roche, 2000). Numerous authors underline however, that the main-focus of these investigations has been the economic dimension and, at a secondary level, social, environmental, and political questions (Chalip, 2006; Lim, 2013; Rojek, 2013). In the context of the $2014 \mathrm{WC}$ in Brazil, the stadium infrastructure projects led to numerous other changes, which go far beyond simple infrastructural ones. According to this logic, material outcomes in terms of infrastructure of the new sporting arenas, promotes other consequent social and institutional changes. In this investigation, we will take as our main object of study, the impact of the organization of the $2014 \mathrm{WC}$ on the national football scene, especially in terms of the country's sporting infrastructure, the relevant Brazilian football bodies, and the fans of the national clubs. Through field research carried out in four host cities, Belo Horizonte, Manaus, Recife and Rio de Janeiro between the years 2013 and 2015, we will seek to consider the question of the impact of big sporting events in the Brazilian context.

The organization of the 2014 WC resulted in numerous changes to the national football scene, involving its main actors and institutions. Prior to these structural improvements that occurred between 2010 and 2014, football organization had previously been the object of improvements at the beginning of the dictatorship, specifically in the 1970 's, a time during which the sport became political propaganda for the military government. In 2007, the moment when Brazil was named the 2014 WC host country, after an initial evaluation made by FIFA, the country was found not to have one stadium that met international standards. This finding was especially unexpected given that the Maracanã stadium had just undergone a significant renovation for the 2007 Pan-American games, at an estimated cost of $\$ 100$ million (Reis, Sousa-Mast, Gurgel, \& Duarte, 2013). While the dossier referent to the Brazilian bid was not made public, it is probable that questions relating to the reconstruction of the stadiums had been highlighted given that the precariousness of the local sporting infrastructure could negatively affect the country's nomination as WC host. Indeed, in 2007, such a preoccupation had been publically expressed by the FIFA president Sepp Blatter (FIFA, 2007).

In a similar manner, the local government, Brazilian Football Confederation (CBF), and FIFA did not fully disclose the decision making process for the selection of the host cities for the 2014 WC. However, it is likely that, behind the scenes, a struggle was taking place given that all the Brazilian municipalities had an interest in hosting the event's matches and in receiving allotted investments. Simultaneously, the former president Lula established political networks, in such a way that all of the country's five 
regions were included. Though dialogue with the local population did not occur either at the national or local levels, twelve host cities were nominated in May 2009. The delay in nominating the host cities led to problems in the following years, such as procrastinations in the delivery of infrastructure works, excessive cost, and problems with accountability in terms of the use of public funds (Junior, Gaffney, \& Ribeiro, 2015).

Starting from this contextualization, the study intends on analyzing the main episodes in Brazilian football beginning from 2007, the year in which Brazil was selected to be the 2014 WC host country. We start from three main questions: (a) adaptation of Brazilian football clubs starting in 2007, (b) the reconfiguration of the country's sporting infrastructure, and (c) the direct impact of the $2014 \mathrm{WC}$ on Brazilian football, leading to a 'gentrification' of the country's most played sport.

\section{Methodology}

This longitudinal study relies on qualitative precepts using the methods of participant observation and semi-structured interview tools, as well as documentary research. Fieldwork was carried out on three occasions between the years of 2013 and 2015, with an average duration of three months, in four host cities of the 2014 WC: Belo Horizonte, Manaus, Recife and Rio de Janeiro. Longitudinal surveys allow for a better causal pathway as well as an examination of changes over time.

Fieldwork was conducted initially in the cities of Belo Horizonte and Rio de Janeiro during the organization of the 2013 Confederations Cup. At the time, various demonstrations were being organized in the country targeting the overspending in the organization of the 2014 WC. The second stage took place during the WC (June and July, 2014) in the four previously mentioned host cities. At that time, careful planning was used to able to stay an equal period in each of the four cities analyzed. In the figure below, we present some details of the field research carried out during the competition. To analyze the impact over the short and medium terms, a third period of fieldwork was undertaken in the same four host cities during the months of June and August 2015.

Participant observation is a strategy of inquiry which in its most characteristic form involves the ethnographer participating either overtly or covertly in people's daily lives for an extended period of time, observing what happens, listening to what is said, asking questions, in fact, collecting whatever data is available to understand the issues that the research focuses on (Hammersley \& Atkison, 1995). This method was applied in order to observe the transformation that occurred in football stadiums (tangibles impacts) of the four host cities analyzed, as well as the behavior and demographic composition (intangible impacts) of fans present at the matches.

Qualitative interviews are particularly useful as a research tool to understand individual's attitudes and values, things that cannot be necessarily be observed or included in a formal questionnaire. Open-ended and flexible questions are likely to get a more considered response than closed questions. Therefore, they provide better access to an interviewees' views, interpretations of events, understandings, experiences and opinions. In this research, semi-structured interviews were conducted with key actors from Brazilian football, divided into four groups: journalists specialized in Brazilian football, presidents of football clubs based in the four host cities considered, fans, and managers directly responsible for stadiums. A total of 57 interviews were conducted with 26 individuals between 2013 and 2015 . Information concerning interviews are presented in the table below.

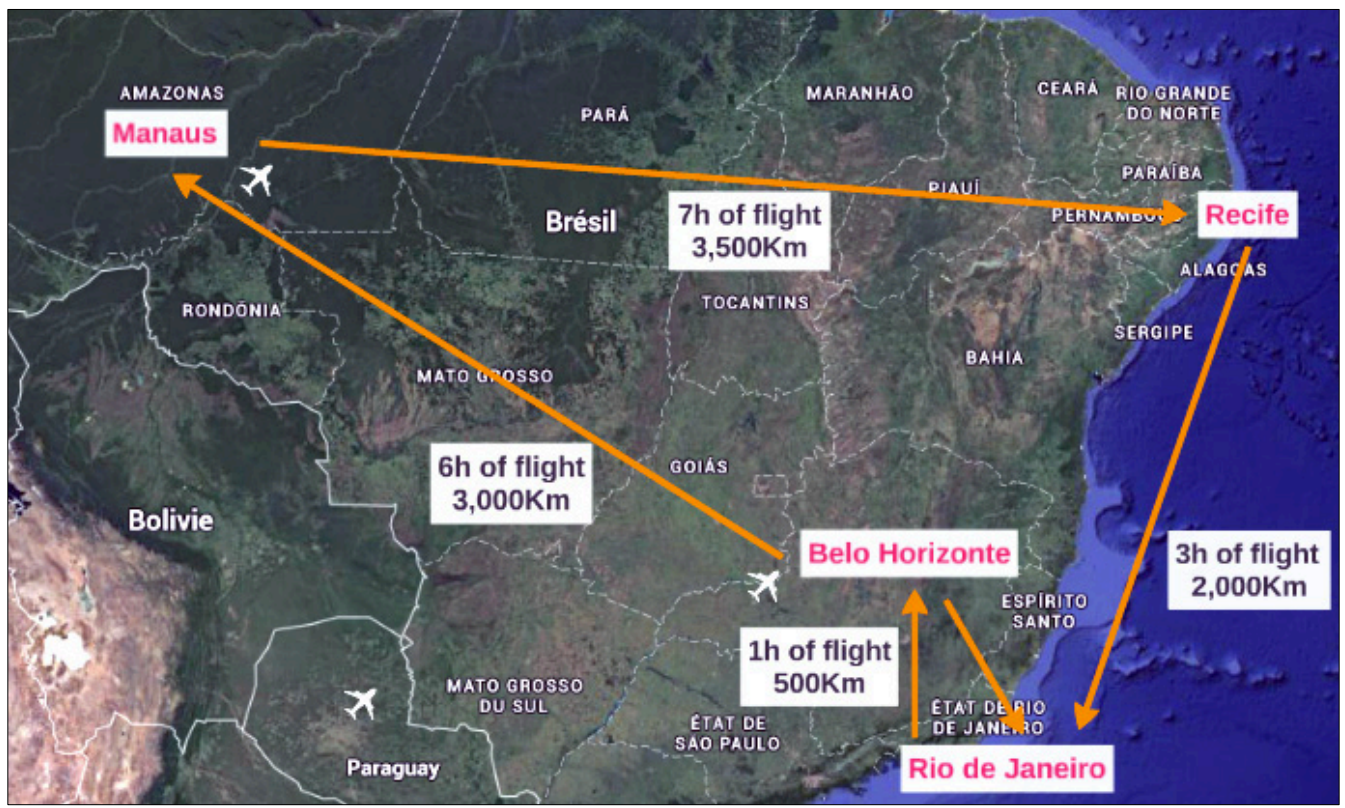

Figure 1. Schema of the 2014 Fieldwork during the WC in Brazil 
Table 1. Information on interviews conducted during the research (2013-2015)

\begin{tabular}{|c|c|c|c|}
\hline Groups & Dates (Year) & $\begin{array}{c}\text { Number of actors and } \\
\text { interviews }\end{array}$ & Themes discussed \\
\hline \multicolumn{4}{|c|}{ Belo Horizonte } \\
\hline Journalists & $2013,2014,2015$ & $\begin{array}{l}1 \text { individual } \\
3 \text { interviews }\end{array}$ & $\begin{array}{c}\text { Football history } \\
\text { Stadiums and Politics }\end{array}$ \\
\hline Presidents of local clubs & $2013,2014,2015$ & $\begin{array}{l}2 \text { individuals } \\
6 \text { interviews }\end{array}$ & $\begin{array}{c}\text { Stadiums } \\
\text { Relationship with CBF and FIFA }\end{array}$ \\
\hline Fans & $2013,2014,2015$ & $\begin{array}{l}3 \text { individuals } \\
9 \text { interviews }\end{array}$ & $\begin{array}{c}\text { Stadiums } \\
\text { Changes after the } 2014 \mathrm{WC}\end{array}$ \\
\hline $\begin{array}{l}\text { Managers responsible for } \\
\text { stadiums }\end{array}$ & 2015 & $\begin{array}{l}1 \text { individual } \\
1 \text { interview }\end{array}$ & $\begin{array}{c}\text { Stadiums } \\
\text { Relationship with the local clubs }\end{array}$ \\
\hline \multicolumn{4}{|c|}{ Manaus } \\
\hline Journalists & 2014,2015 & $\begin{array}{l}1 \text { individual } \\
2 \text { interviews }\end{array}$ & $\begin{array}{c}\text { Football history } \\
\text { Stadiums and Politics } \\
\end{array}$ \\
\hline Presidents of local clubs & 2014,2015 & $\begin{array}{l}1 \text { individual } \\
2 \text { interviews }\end{array}$ & $\begin{array}{c}\text { Stadiums } \\
\text { Relationship with CBF and FIFA }\end{array}$ \\
\hline Fans & 2014,2015 & $\begin{array}{l}3 \text { individuals } \\
6 \text { interviews }\end{array}$ & $\begin{array}{c}\text { Stadiums } \\
\text { Changes after the } 2014 \text { WC }\end{array}$ \\
\hline $\begin{array}{c}\text { Managers responsible for } \\
\text { stadiums }\end{array}$ & 2015 & $\begin{array}{l}1 \text { individual } \\
1 \text { interview }\end{array}$ & $\begin{array}{c}\text { Stadiums } \\
\text { Relationship with the local clubs }\end{array}$ \\
\hline \multicolumn{4}{|c|}{ Recife } \\
\hline Journalists & 2014,2015 & $\begin{array}{l}1 \text { individual } \\
2 \text { interviews } \\
\end{array}$ & $\begin{array}{c}\text { Football history } \\
\text { Stadiums and Politics }\end{array}$ \\
\hline Presidents of local clubs & 2014,2015 & $\begin{array}{l}1 \text { individual } \\
2 \text { interviews }\end{array}$ & $\begin{array}{c}\text { Stadiums } \\
\text { Relationship with CBF and FIFA }\end{array}$ \\
\hline Fans & 2014,2015 & $\begin{array}{l}3 \text { individuals } \\
6 \text { interviews }\end{array}$ & $\begin{array}{c}\text { Stadiums } \\
\text { Changes after the } 2014 \mathrm{WC}\end{array}$ \\
\hline $\begin{array}{c}\text { Managers responsible for } \\
\text { stadiums }\end{array}$ & 2015 & $\begin{array}{l}1 \text { individual } \\
1 \text { interview }\end{array}$ & $\begin{array}{c}\text { Stadiums } \\
\text { Relationship with the local clubs }\end{array}$ \\
\hline \multicolumn{4}{|c|}{ Rio de Janeiro } \\
\hline Journalists & $2013,2014,2015$ & $\begin{array}{l}1 \text { individual } \\
2 \text { interviews }\end{array}$ & $\begin{array}{c}\text { Football history } \\
\text { Stadiums and Politics }\end{array}$ \\
\hline Presidents of local clubs & 2013,2014 & $\begin{array}{l}1 \text { individual } \\
2 \text { interviews }\end{array}$ & $\begin{array}{c}\text { Stadiums } \\
\text { Relationship with CBF and FIFA }\end{array}$ \\
\hline Fans & $2013,2014,2015$ & $\begin{array}{l}3 \text { individuals } \\
9 \text { interviews }\end{array}$ & $\begin{array}{c}\text { Stadiums } \\
\text { Changes after the } 2014 \text { WC }\end{array}$ \\
\hline $\begin{array}{c}\text { Managers responsible for } \\
\text { stadiums }\end{array}$ & 2015 & $\begin{array}{l}2 \text { individuals } \\
2 \text { interview }\end{array}$ & $\begin{array}{c}\text { Stadiums } \\
\text { Relationship with the local clubs }\end{array}$ \\
\hline
\end{tabular}

In addition to the methods described above, this study also included documentary analysis from 2007 to 2016 . Documentary research is essential to the extent that it allows us a 'behind the scenes' look, triangulation, to trace the genealogy of ideas, to provide another dimension for our data, and to provide access to marginalized voices (Seale, 2011). The documents analyzed in this research can be divided into: official records, reports published by institutions linked to football, articles published in journals, and articles published by non-governmental organizations. The documentary sources collected were analyzed using content analysis, which enabled us to create categories and code data directly according to what was put forward in the sources (Hsieh \& Shannon, 2005).

\section{Results and Discussion}

\subsection{Adaptation of Brazilian Football Clubs Starting in 2007}

Though infrastructure works on Brazilian stadiums started in 2010, it was in 2007 that the first signs of the transformation of the Brazilian football scene started to take place. Up until this moment, the institutions responsible for the football did not dedicate themselves in a professionalized and modernized fashion. In terms of the football clubs, the professionals involved did not have the required skills for the relevant positions, and interaction with the football world occurred mainly by way of club loyalty and/or nepotism. During this period, the country's best players were contracted, while still adolescents, by the European clubs where the leagues had a better structure with more attractive salaries. Consequently, the Brazilian teams were made up of players trained by the base or by players who came back to Brazil after long periods overseas. Currently, even though many Brazilian players are still spread around the European clubs, an improvement in the buying power of Brazilian clubs, notably in the first division, has allowed the retention of players for longer periods and the payment of more competitive salaries (CIES, 2015). According to a study published in 2012 by the UEFA, practically all European countries have Brazilian players in their national leagues. 
Table 2. Number of Brazilian Players in Foreign Top-Flights

\begin{tabular}{|c|c|}
\hline Countries & Number of Players \\
\hline Portugal & 130 \\
\hline Italy & 46 \\
\hline Cyprus & 32 \\
\hline Romania & 26 \\
\hline Ukraine & 25 \\
\hline Bulgaria & 25 \\
\hline Russia & 24 \\
\hline France & 24 \\
\hline Spain & 22 \\
\hline Malta & 21 \\
\hline Turkey & 21 \\
\hline England & 16 \\
\hline
\end{tabular}

Taking this into account, firstly, the main national clubs began to contract more qualified professionals in the areas relevant to management to respond to new sporting demands. Gradually, the status quo politics of Brazilian football, based especially in political nepotism began to weaken. From there on, we see a transformation of the process of strategic decision-making, which led to the establishment of the "partner-fan" system. It is worth noting that European clubs, from the start of the 2000's, had already implemented this tool with the aim of signing up a greater number of club members. Such a strategy allowed an increase in the brute income of clubs, reducing the dependency on payments related to image rights, and the marketing of players.

From then on, it was necessary to pay a monthly fee to the club to be able to see one of their matches. This project allowed the clubs a base level of ensured income, which contributed to new contracts and to the retention of valuable players on the international market. Beyond this new policy aimed at club members, the so-called "new arenas", planned for the 2014 WC, would be aimed at attracting more spectators, bringing together a greater number of "partners", as some studies have shown (Szymanski \& Brut, 2014).

Indeed, numerous national football clubs had to adapt themselves to the new situation surrounding sporting infrastructure demanded by the arrival of the 2014 WC. Considering this, at this precise moment, the majority of the country's stadiums were public institutions. Therefore, various clubs were obliged to find other stadiums in which to play their matches scheduled on the national calendar. In the specific case of the "Athletic Mineiro" club, the president Mr. Nepomuceno, pointed out that for more than three years, games played by his team took place in the city of Sete Lagoas, located more than seventy kilometers from Belo Horizonte.

Beyond these obstacles in terms of sporting infrastructure, there are various signs of an absence of communication or agreement between the CBF, FIFA and Brazil's football clubs regarding the duration of the stadiums' construction works and the setbacks that these measures would generate.
In other words, for more than three years, the Brazilian football scenario underwent profound alterations given that the main stadiums were maintained closed for preparations to receive the WC matches.

Simultaneously, beyond institutional conflicts between clubs and the 2014 WC organizing bodies, the majority of the stadium construction was considerably delayed, hampering club logistics and the movement of fans. While the Minerão had been the second stadium to be delivered for the WC, immediately after the stadium in Fortaleza, its restructuring went through numerous hold-ups, such as strikes and suspicion of embezzlement of public funds, resulting in a delay of more than six months (Portal da Copa, 2015).

These initial events starting in 2007, can be considered driving factors for a radical transformation in the organization of football in the country, especially in terms of Brazil's clubs. After the implementation of the "partner-fan" system, the clubs noticed that the Brazilian people's most popular sport could be exploited in a more effective manner to create a regular monthly profit (Gaffney, 2015).

Generally, the sport was being economically underexploited by its managers due to the poor management of sporting infrastructure, which did not favor an increase in the number of members, nor the possible adjustment of ticket prices. Practically all the country's first division clubs also held significant debt from the payment of interest and for loans taken out with private banks. For example, the three most popular clubs from Rio de Janeiro, Flamengo, Vasco, and Botafogo, currently have debts of around \$200 million (Lance, 2015).

At this point, there were numerous other unanswered questions, mainly in terms of the stadiums' new managers. The organizers predicted a reduction in the participation of public bodies in the management of the new arenas and highlighted a new form of management based in public-private partnerships. On the other hand, we equally saw a certain excitement of the Brazilian clubs, because, once the works are concluded, high quality stadiums would be available for the Brazilian teams.

\subsection{The New Configuration of Brazil's Sporting Infrastructure}

While Brazilian football prospered on the field from the 1940 's, the construction of Brazil's stadiums was interrupted at the end of the period of the dictatorship, which lasted from 1964 to 1985 (Novais, Cagnin, \& Júnior, 2015). In the final years of the dictatorship, there was a loss of interest in investment in the sporting sphere given that the government's administration found itself in decline, confronting significant popular opposition. The country's main leaders already had a stadium of significant size and the period of large infrastructure investments had already reached its peak (Gaffney, 2015). In a situation of hyperinflation and a return to democracy, the old stadiums were sufficiently capable of hosting important games. 
Though these stadiums were not seen as the most modern in the world, "the majority of them responded adequately to the desire and demand of the Brazilian public, this public in love with and connected to football culture" (Wisnik, 2008, p. 146).

Despite this, starting from the 1990's, just as with other urban infrastructure in the country, the stadiums began to suffer from a natural process of wear, due to a lack of maintenance, which over time made the appropriate use of this infrastructure impossible (Gaffney, 2015). Due to this process, as well as the emergence of organized club members involved in violent acts, frequenting stadiums began to be seen as dangerous, leading to a reduction in spectator numbers (Gaffney \& Melo, 2010).

On a number of occasions, this neglect resulted in significant tragedies. In 1992, moments before the final of the Brazilian League in Salvador, part of the stands of the Fonte Nova stadium collapsed, causing numerous fans to fall, leading to the death of three. In 1995, during a friendly game between the teams the Corinthians and Taubaté, part of the supports of the stands seriously buckled injuring more than twenty people. In 2000, in Rio de Janeiro, a fence without adequate maintenance at the São Januário stadium gave way due to an excessive number of fans causing the death of more than one hundred and eighty five individuals. In 2007, in Salvador, again in the Fonte Nova Stadium, a large part of the stands gave way, provoking the fall of tens of people from a height of more than fifteen meters (Gaffney, 2015).

At the same time, organized fans were gaining force and financial support from clubs, exacerbating the fear of going to the stadiums. Public stadiums were seen as unsafe places of heightened violence. This situation drove initial discussions at the heart of the Federal Government leading to the implementation of control measures to combat the direct causes of the problem. Thus, we see attempts at regulating football and the sporting infrastructure, particularly with the implementation of the "Lei Pelé", in 2001, and the "Lei dos Torcedores" (The fan's law) in 2003 (Presidência da República, 2003). Despite such governmental interventions, the implementation of still more stringent measures would be necessary to ensure that a reduction of violence took place, at the same time that the stadium structures were improved.
Prior to the $2014 \mathrm{WC}$ opening, the CBF (2015) carried out a study into the main characteristics of Brazilian stadiums with the intention of producing an overview of the sporting infrastructure. Though there is imprecision in the documents analyzed, the data presented, provided us with a good understanding of the sport. The majority of the states are situated in the Southeast and Northeast regions, which confirms the demographic concentration of these regions, as well as the large number of teams in the first and second divisions of the national league. The majority of these stadiums are public responsibility and the private stadiums tend to be smaller and are concentrated mainly in the South and Southeast. In terms of size, $84 \%$ of the Brazilian stadiums possess a capacity smaller than 15,000 spectators.

When comparing the new data concerning the Brazilian stadiums with that published by the $\mathrm{CBF}$, we see a considerable change in the Brazilian football scenario after Brazil's being named the 2014 WC host. As such, the demands made by FIFA in terms of sporting infrastructure provoked numerous alterations in the general makeup of football in Brazil. Beyond the improvements in relation to the stands, restaurants, locker rooms, and parking, all of the reconstructed stadiums for the 2014 WC underwent a reduction of at least $50 \%$ of their capacity. For example, in Belo Horizonte, the Minerão went from a capacity of 130,000 spectators to 62,000 . In Rio de Janeiro, the Maracanã, previously the largest stadium in the world, went from a capacity of 150,000 to 78,000 spectators.

This first major change in terms of capacity was also responsible for a noticeable growth in the scarcity of tickets for the fans (Portal da Copa, 2014). As a result, the cheaper sections, known as "gerais", were completely eliminated under the pretext of a lack of comfort and for being dangerous. These sectors, characteristic of Brazilian stadiums since the 1950's, not only represented the cheapest seats for working class fans, but were also responsible for the joy and festivity of the matches. The "gerais" were always synonymous with partying and creativity. In the photo shown below, taken during a game of the Brazilian team at Maracanã in 1985, one sees the energy of the "gerais" sector and its proximity to the field.

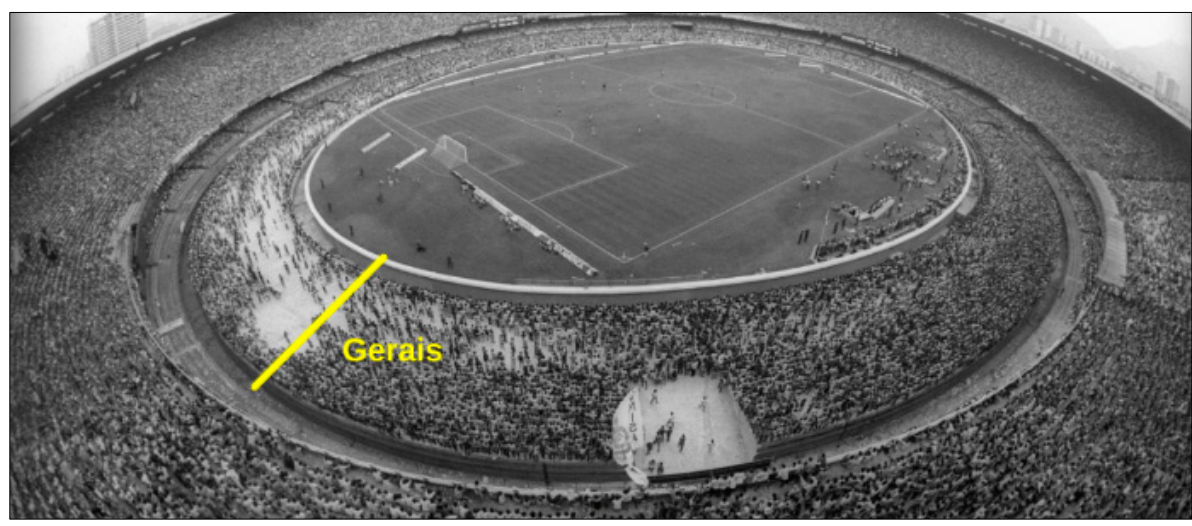

Figure 2. Maracanã Stadium during a match between the Brazilian and the Paraguayan teams 
If on one hand, the planned improvements generated more security and comfort for Brazilian fans, on the other hand, we see a transformation of popular sectors into VIP sectors. Gradually, the country's big public stadiums, originally designed to receive the whole spectrum of social classes, were being replaced by new private, multifunctional arenas requiring an elevated maintenance cost, frequently with public expenditure tied in as well. It is owing to this that Brazilian football is currently suffering a process of gentrification, which over the long-term could compromise an essential element of popular national culture (DaMatta, 1982).

\subsection{Direct Impacts of the 2014 WC on Brazilian Football}

The benefits to Brazilian stadiums due to the arrival of the 2014 WC in Brazil are undeniable. The country's twelve host cities, as well as clubs and fans, welcomed these changes, despite elevated construction costs and future uncertainty regarding some of the arenas (Júnior, 2015). Since the 1980's, Brazilian stadiums found themselves to be increasingly obsolete and not commensurate to the enormous commitment of Brazil's football fans. Consequently, prior to the 2000's, we see a significant fall in the public attending the stadiums of the capitals, which was certainly related to their neglect and to the increase in violence amongst fans (Gaffney, 2015).

Beyond the benefits, prior to the $2014 \mathrm{WC}$, the management of the Brazilian stadiums was a public responsibility. For example, in 2010, amongst the twenty teams present in the first division of the Brazilian league, only three teams possessed their own stadium, with the other seventeen using public ones (Gaffney, 2015). Currently, one year after the WC, numerous teams have constructed their own arenas, at the same time as the old public stadiums were privatized through public-private partnerships. Therefore, over the long term, the expenses referent to maintenance increased, due to improvements and the level of management by the responsible companies, generating a consequent growth in the value of rents paid by Brazilian clubs.

All these transformations equally had an effect on the Brazilian teams' fans. Just as Brazil was named the 2014 WC host country, we see a gradual increase in ticket prices, mainly in the new stadiums (Portal da Copa, 2014). From thereon, we equally find a shift in the socio-demographic composition of the public attending this new sporting infrastructure.

In 2013, during the final of the Liberators' Cup of America in the city of Rio de Janeiro, a short while after the reopening of Maracanã, the Sporting journalist Juca Kfouri, commentating directly on a game for a Brazilian television channel declared:

It is unbelievable what is happening! From where I'm sitting, I can't see a single black person in the stadium. Honestly, such a situation leaves me truly uncomfortable and certainly this should be understood as one of the first signs of a change of profile of the Brazilian fans after the structural changes to the stadiums for the 2014 WC. (Interview carried out in São Paulo on the 22nd of July 2014)

As such, in a country where more than half the population (51\%) considers itself "black" or "mixed" (IBGE, 2014), the evaluation of Juca Kfouri warrants noting. In general, we currently see an increasingly middle class demographic for the fans, mainly owing to growing ticket prices tied to the implementation of the "partner-fan" program, and due to new arena management. Taking into consideration that the country's arenas were reconstructed according to FIFA regulations, the less well-off fans found themselves excluded from attending these new stadiums. If on one hand, the new structural changes follow a global tendency typical of big sporting events (Spracklen, 2009), on the other hand, taking into account the Brazilian population, we see that the local authorities did not consider at any time the socioeconomic state of the country.

According to study (Seitz, 2015), currently, Brazilians need to work on average ten hours and twelve minutes to be able to buy a ticket for a first division national league football match. In this analysis, the author divides the value of the minimum wage of a number of countries around the world, by the number of hours worked according to local legislation. For example, in France, to see a Paris Saint-Germain match, the fan would work two hours and thirty-six minutes to be able to buy a ticket. Even in Argentina, the country with socio-economic conditions closest to those of Brazil's, the local fan needs to work three hours and thirty minutes. In truth, the Brazilian ticket is the most expensive in the world when compared with the value of the minimum wage and the forty-four hour working week defined in the constitution. It is worth noting that in 2012, more than $60 \%$ of the Brazilian population lived on less than one minimum wage per month (\$250) (IBGE, 2014).

Since 2013, a great number of reports have been looking into the question of the substantial increase in ticket prices in the country's new stadiums. When we compare prices established between the Brazilian championships from 2012 and those of 2013, exactly after the finalization of the constructions for the $2014 \mathrm{WC}$, we see a growing median of $300 \%$, that is to say, from $\$ 3,3$ to $\$ 13$. Throughout the year, when comparing the prices set in the old stadiums with those of the stadiums reconstructed for the WC, we see a difference of $119 \%$. During this period, fans who attended the new stadiums spent two times more to be able to see a match.

Pluri (2015) showed the average difference between ticked prices for the new and old stadium is $85 \%$. The study also shows that the number of spectators present in the new stadiums increased $29 \%$ in relation to the public prior to the opening of the WC, provoking a growth of final income of $85 \%$ for each game scheduled. As such, when we compare the new stadiums with old ones, this difference in the public is in the order of $88 \%$ and $249 \%$ when we analyze the brute 
profit per match. Therefore, taking into consideration only economic questions, we see that the new stadiums, in general, contribute to an increase in profitability relative to the matches, equally provoking a change in the socioeconomic profile of fans.

While the numbers are unequivocal, if analyzing them independently, we should also consider other factors. In practice, when we compare the presence of the Brazilian public in the stadiums with other championships carried out around the world, Brazil remains in last position, which contradicts the cultural centrality of the sport in the country. For example, though an increase of $15 \%$ between the 2012 and 2013 (Szymanski \& Brut, 2014), the average crowd in the Brazilian league in 2013 was 14,951 people, which confers on the country the $15^{\text {th }}$ ranking amongst the twenty main world champion countries. In Germany, the first country on the list, the "Bundesliga" shows an average public of 43,173 people per match (Pluri Consultoria, 2015).

These numbers refer to the attendance of the public in the stadiums, according to a study published one year after the 2014 WC final looking into the current management of Brazil's stadiums, between the twelve competition stadiums, eight show financial difficulties (Folha de São Paulo, 2015). In 2014 , the total liability was more than $\$ 42$ million. In terms of the stadiums studied throughout this research, those in Manaus, Recife, and in Rio de Janeiro are burdened by considerable losses since the end of the $2014 \mathrm{WC}$, while the stadium in Belo Horizonte shows growing profits. This information is shown in the table below:

In Manaus, the situation is seen as serious, taking into consideration that the city has no team able to attract more than 40,000 spectators, which is the stadium's maximum capacity. Since opening at the beginning of 2014, only fifteen games have been played there. According to its managers (The State of Amazonas), beyond simply the lack of a team in the first division of the National League, the cost of its maintenance also represents a liability. Currently, these expenses are around \$2 million a year, undercutting any hope for a profit in the short term. Due to this, the Sate of Amazonas is looking for a private enterprise interested in the venture that would be able to exploit the new stadium's diverse uses, such as for the organization of cultural events.

In Recife, though four renowned teams are present in the first division of the National League, we see a reduction of public and a growth of debt related to the new stadium's management. According to local authorities, one of the main drivers of this situation is the stadium's distance, located as it is in the city of São Lourenço da Mata, around 20 kilometers from the center of Recife. Since the end of the 2014 WC, despite the 52 games organized by the company responsible for the stadium in Pernambuco, the average public was only $23 \%$ of capacity. According to a local study (Zirpoli, 2015), the average crowd went down from 12,305 in 2014 to 10,680 in 2015 , though the ticket price had dropped from $\$ 8$ to $\$ 7$.

In terms of the Maracanã stadium in Rio de Janeiro, according to the current managers, some adjustments are still required such that, over the long term, the stadium can be considered more profitable. One year after the end of the 2014 WC, Maracanã experienced an estimated liability of $\$ 500$ million, the biggest amongst the twelve competition stadiums. Even with 76 matches happening during this time, we see that the high cost of maintenance of the space, calculated at around $\$ 12$ million a year, does not favor profit. Beyond this, according to those responsible for its management, the current placement of the clubs in the National League, one of the worst in recent years, does not contribute to an increase in spectators.

Different to the other cities, in Belo Horizonte, Mineirão stadium shows an estimated profit of around \$5.6 million since the end of the 2014 WC. According to a study taking into consideration all the stadiums used in the Brazilian League for the first and second divisions throughout 2015, the Mineirão is the fourth placed in terms of public with an average per match of 22,500 people, that is, 7,500 fans more than the national average (Lemos, 2015). During field research, we carried out a study at the Mineirão on the $27^{\text {th }}$ of June 2015 and, on that occasion, there were more than 45,392 fans, which generated a brute profit evaluated at $\$ 600,000$.

Table 3. Condition of the Stadiums one year after the 2014 WC

\begin{tabular}{|c|c|c|c|}
\hline $\begin{array}{c}\text { Host } \\
\text { Cities }\end{array}$ & Number of games after the 2014 WC & Final Revenue & Financial Situation \\
\hline $\begin{array}{c}\text { Manaus } \\
\text { Amazonas' Arena }\end{array}$ & 15 matches & $\$ 1,5$ million & $\begin{array}{c}\text { Financial loss: } \\
\$ 500,000\end{array}$ \\
\hline $\begin{array}{c}\text { Recife } \\
\text { Pernambuco's } \\
\text { Arena }\end{array}$ & 52 matches & $\$ 7$ million & $\begin{array}{c}\text { Financial loss: } \\
-\$ 7,7 \text { million }\end{array}$ \\
\hline $\begin{array}{c}\text { Rio de Janeiro } \\
\text { Maracanã's Stadium }\end{array}$ & 76 matches & $\$ 20$ million & $\begin{array}{c}\text { Financial loss: } \\
-\$ 22 \text { million }\end{array}$ \\
\hline $\begin{array}{c}\text { Belo Horizonte } \\
\text { Mineirão's Stadium }\end{array}$ & 45 matches & $\$ 20$ million & $\begin{array}{c}\text { Financial profit: } \\
+\$ 5,6 \text { million }\end{array}$ \\
\hline
\end{tabular}


All this information shows the ambiguities and difficulties confronted by the responsible authorities, intending to improve the condition of the sport in Brazil. What are the strategies that should be adopted then, so that the situation can be turned around? During the fieldwork, we found out that there is no clear difference between the analyses of the presidents of the clubs and the fans. Both agree regarding the reduction of ticket prices. Despite this, after the realization of the WC and consequent privatization of the stadiums, the cost of this infrastructure increased significantly making a reduction of the ticket prices for the new stadiums impossible. Following this logic, in August, 2015, the Federal Government voted on a new law determining financial assistance for the clubs who quit their debts with the national treasury. According to this document, the government commits itself to subsidizing a part of the price of the cheaper tickets for defaulting teams (Governo do Brasil, 2015).

Beyond government initiatives, we equally see discussions at the heart of the Brazilian clubs. Indeed, after realizing the $\mathrm{WC}$ and the complete removal of the "gerais", we can see a radical change in the atmosphere at the games, leading to a loss of expressive emotion characteristic of the sport and its competitiveness.

Currently, Brazilian football is undergoing a clear "gentrification", which compromises an important part of the cultural formation of the country's population. The architectonic project, as beautiful as it is, equally leads to behavioral changes from its users, in this case, the fans. In other words, mainly taking into consideration the sociological aspects related to the question, the manner in which we move ourselves and express ourselves relates to a convergence of signs and significant cultural heritage (Mauss, 1970). The way in which we walk, talk, in which we behave ourselves or barrack for our football team, can reveal diverse things about ourselves. In this sense, every gesture, as inoffensive as it may seem is a political and transformative one.

When an architectonic project primarily seeks the "comfort of the fan", such as the projects conceived by the companies responsible for the works on the 2014 WC stadiums, and further, invites participants to remain seated and passive, we notice in truth an attempt to control the behavior of individuals. Not all the people present in the arena wish to remain seated, or wish to be distant from each other, or only want to see the football match. From this perspective, according to the research of Coelho (2014, p. 16), regarding the imaginary of the stadium and fans' first memories there, "the spectators firstly remember the atmosphere of the games and the fans and, secondly, the match and events that take place on the field". In this sense, fans view the match as a party and the atmosphere of the games that is kept in their memories is not necessarily the comfort amongst the members.

Accepting this, what would the real cultural impact of the new Brazilian stadiums be, having as their point of support this new behavior imposed on fans? In the majority of cases, the new stadiums were inspired by the model of the European stadiums, completely excluding the participation of fans and clubs from the decision making and conception process for the new infrastructure. According to three managers interviewed in the field research in 2014, evoking the conflict between the culture of the fans and the new project for the numbered seats in the stadiums, all underline the same aspects:

We wish to establish a greater dialogue with the clubs and fans, without, however, altering this new culture of football based notably in spectacle. We have to value the game, the show that football can provide, and demand this. Football is a sport that can generate a much greater financial gain. Our model is the European one where the stadiums were transformed into grand media spectacles. Going to a stadium should be seen as a singular experience. The consumption should start already at the entrance to the stadium and continue until leaving it. In this way, we are capable of attracting new investors and sponsors. (Transcription of Interview carried out during the 2014 WC)

The managers talk openly about a "new culture" for a new form of consumption. We take as our analysis one of the main symbols of this new culture: the seat or chair. Is it not precisely the seat or chair, which distances us when we wish to celebrate something or create a festive atmosphere? As such, where there are an excessive number of places or seats, normally there is no party. True festive gatherings, analyzed as universal phenomena, are only viable if a measure of instability is present (Clastres, 2011). Starting from the moment in which we accept sharing something in a group, we are accepting the risks and pleasures inherent in such a situation. "Get up means to share and socialize with others. On the other hand, to sit down means to return to oneself, which is only permitted after complete exhaustion" (Coelho, 2014, p. 13).

\section{Conclusions}

What we observe in the contemporary Brazilian football scene is the implementation of control measures for both fans and players, by way of an architectonic project lacking originality, and which leads to social exclusion related to the citizen's purchasing power. Since the arrival of the 2014 WC, we see a "gentrification" as much of the urban space, through the new "centralities", as of the sporting infrastructure (Dansero \& Puttilli, 2010; Gaffney, 2015). On the other hand, we equally see a critical movement against these restrictions by way of the emergence of new groups and the implementation of new measures.

From this perspective, the Federal Government seeks to draw closer to the Brazilian clubs, as well as the players associations, having as its main objective the weakening of 
the power exercised by the $\mathrm{CBF}$ on the national scene. According to researchers (Junior, Ribeiro, \& Gaffney, 2015), the first step is to prioritize the breaking of the hegemony of the $\mathrm{CBF}$ on the control of Brazilian football and, following from this, restructuring the other participating institutions, such as clubs, associations, federations, players, umpires, and fans. These first steps approved by the Government represent a significant advance for the reconfiguration of the sport, though other actions would be equally necessary.

We notice that the process of organization for the 2014 WC shook up the situation of Brazilian football in diverse ways. After the publication of the corruption scandals involving FIFA and the CBF more than twenty years ago (Jennings, 2015), the Federal Government decided to move closer to the country's professional players association, named "Good sense Sport Club", to discuss a series of questions pertinent to the sport's national structure. The relevant bodies are evaluating other measures in this same direction that would equally benefit the sport over the medium and long terms.

Taking into consideration the previously outlined facts, we can conclude that the organization of the $2014 \mathrm{WC}$ provoked significant changes in numerous ways for Brazilian football, as much in terms of infrastructure as management of the sport. In relation to new stadiums, we should mention that over the short term the managers were still unable to implement the necessary measures capable of generating real profits, though ticket prices had been steadily going up since the beginning of the event. The high cost of the new sporting infrastructure did not favor a price reduction policy for tickets, at the same time as the public, when compared with the public in other countries, remained below its real potential. According to this new logic, the big losers seem to be the working class fans who are not able to acquire the tickets. Financed with public money and controlled by private interests, WC stadiums have been used as worlds of consumption isolated from their urban and cultural contexts (Bauman, 2007).

Previously, regarding the management of the sport in Brazil, we find an attempt at implementing new measures for the football clubs to professionalize the team's administration. We see an important change starting from the adoption of "partner-fan" system whose main objectives was to sign up members to sustain a fixed monthly income for the clubs. However, we find that the majority of the teams in Brazil show significant public debt, hampering the adequate management of these institutions (Gaffney, 2015). In Brazil, since the end of the $2014 \mathrm{WC}$, the Federal Government is seeking solutions in terms of an approximation with the soccer clubs, and via certain proposals for favoring the payment of taxes. Further, the Sports Ministry, in association with the "Good Sense Sporting Club", is seeking to reduce the power exercised by the CBF with the aim of conceding greater freedom to the country's professional players in the management of their careers.

\section{REFERENCES}

[1] Bauman, Z. (2007). Consuming Life. Cambridge: Polity Press.

[2] CBF. (2015, novembre 28). Reunião Comissão Nacional de Inspeção de Estádios. Retrieved from http://www.cbf.com.br/central-de-fotos/campeonatos/

[3] Chalip, L. (2006). Towards social leverage of sport events. Journal of Sport \& Tourism, 109-127.

[4] CIES. (2015, may 13). Centre International d'étude du sport. Retrieved from http://www.cies.ch/fr/cies/accueil/

[5] Clastres, P. (2011). Arqueologia da violência: pesquisas da antropologia política. São Paulo: Cosac Naify.

[6] Coelho, G. (2014). O cotidiano de torcidas jovens de futebol: indícios da saturação da racionalidade moderna. Rio de Janeiro: UERJ.

[7] DaMatta, R. (1994). Antropologia do óbvio: notas em torno do significado do futebol brasileiro. Revista da USP, 10-17.

[8] Dansero, E., \& Puttilli, M. (2010). Mega-events tourism legacies: the case of the Torino 2006 Winter Olympic Games territorialisation approach. Leisure Studies, 29(3), 321-341, doi: $10.1080 / 02614361003716966$

[9] FIFA. (2007). FIFA financial report 2006. Retrieved from http://www.fifa.com/mm/document/affederation/administrati on

[10] Folha de São Paulo. (2015, june 12). Um ano depois da Copa, oito dos 12 estádios têm prejuízo. Retrieved from http://www.folha.uol.com.br

[11] Gaffney, C. (2015). Arenas de conflito: os processos conflituosos durante a preparação para a Copa do Mundo no Brasil. In O. A. Junior, C. Gaffney, \& L. C. Ribeiro, Brasil: os impactos da Copa do Mundo 2014 e das Olímpiadas 2016 (pp. 185-202). Rio de Janeiro: Observatório das Metrôpoles.

[12] Gaffney, C. (2013). From Culture to Spectacle: The new logics of Brazilian football. Territorio, 1-12.

[13] Gaffney, C., \& Melo, E. S. (2010). Mega-eventos Esportivos para quem? Proposta, 30-52.

[14] Governo do Brasil. (2015). Dilma sanciona lei do futebol e Brasil dá um grande passo para modernizar o esporte. Retrieved from http://blog.planalto.gov.br/

[15] Hammersley, M., \& Atkison, P. (1995). Ethnography: Principles in Practice. London: Routledge.

[16] Horne, J. (2007). The Four "Knows" of Sports Mega-Events. Leisure Studies, 26(1), 81-96.

[17] Hsieh, H. F., \& Shannon, S. E. (2005). Three approachs to qualitative content analysis. Qualitative Health Research, 15 (9), 1277-1288.

[18] IBGE. (2014). Estimativas da população residente no Brasil e unidades da federação. Brasília: Instituto Brasileiro de Geografia e Estatística.

[19] Jennings, A. (2015). The Dirty Game: Uncovering the Scandal at FIFA. London: Cornerstone Digital. 
[20] Junior, O. A., Gaffney, C., \& Ribeiro, L. C. (2015). Brasil: os impactos da Copa do Mundo 2014 e das Olimpíadas 2016. Rio de Janeiro: E-papers Serviços Editoriais Ltda.

[21] Lance. No vermelho: veja os clubes com as maiores dívidas no Brasil. Retrieved 1104,2015 , from http://esportes.terra.com.br/lance/

[22] Lemos, C. B. (2015). O Público nos estádios do Brasil. Retrieved from http://app.globoesporte.globo.com/futebol/publico-no-brasil/

[23] Lim, Y. (2013). A Critical Review of Social Impacts of Mega-Events. The International Journal of Sport and Society, $3,57-64$.

[24] Müller, M. (2015). What makes an event a mega-event? Definitions and sizes. Leisure Studies, 627-642.

[25] Mauss, M. (1970). Essais de sociologie. Paris: Seuil.

[26] Novais, L. F., Cagnin, R. F., \& Junior, G. B. (2014). A economia brasileira no contexto da crise global. São Paulo: Fundap.

[27] Pluri Consultoria. (2015). O Impacto das novas arenas sobre públicoe a renda do Campeonato Brasileiro. São Paulo: Pluri Consultoria.

[28] Portal da Copa. (2014). Elitização ou popularização do público nos estádios?. Retrieved from http://www.portal2014.org.br/ noticias/12214/
[29] Presidência da República. (2003, may 15). Lei no 10.671, de 15 de maio de 2003. Retrieved from http://www.planalto.gov.br /ccivil_03/leis/2003/L10.671.htm

[30] Preuss, H. (2007). The conceptualisation and measurement of Mega Sport Event Legacies. Journal of Sport \& Tourism, 207-227.

[31] Reis, A., Sousa-Mast, F., Gurgel, L., \& Duarte, P. L. A. (2013). Are cariocas getting ready for the Games? Sport participation and the Rio de Janeiro 2016 Olympics Games. Managing Leisure, 1-17.

[32] Roche, M. (2000). Mega-events and Modernity. London: Routledge.

[33] Rojek, C. (2013). Event Power: how global events manage and manipulate. London: Sage.

[34] Seale, C. (2011). Researching Society and Culture. London: SAGE Publications.

[35] Seitz, O. (2015). A elitização do futebol: ingresso brasileiro é o mais inacessível do mundo. Revista Época, 09-15.

[36] Spracklen, K. (2009). The Meaning and Purpose of Leisure. Habermas and Leisure at the End of Modernity. Basingstoke: Palgrave Macmillan.

[37] Szymanski, S., \& Brut, B. (2014). How football clubs benefit from the World Cup (and Euros). Soccer Economics, 1-22.

[38] Wisnik, J. M. (2008). Veneno Remédio: o futebol e o Brasil. São Paulo: Companhia das Letras 